\title{
EU TENHO A FORÇA: O PODER DAS FIGURAS RETÓRICAS NA PUBLICIDADE IMPRESSA
}

\author{
CELSO FIGUEIREDO NETO \\ MARIA DE LOURDES BACHA \\ SOFIA DERANI
}


EU TENHO A FORÇA: O PODER DAS FIGURAS RETÓRICAS NA PUBLICIDADE IMPRESSA

Resumo: O presente trabalho apresenta resultados de pesquisa empírica cujo objetivo foi verificar a efetividade das figuras retóricas na construção de mensagens publicitárias, a partir de dois grupos de doze anúncios com produtos desejáveis e indesejáveis. As respontas indiciam a ideia de que mais do que as marcas, os recursos retóricos utilizados tendem a ser determinantes nos índices de lembrança e desejo de compra dos produtos anunciados.

Palavras-Chave: Publicidade; retórica, comunicação, marcas.

YO TENGO LA FUERZA: EL PODER DE LAS FIGURAS RETÓRICAS EN LA PUBLICIDAD IMPRESA

Resumen: El presente trabajo presenta resultados de investigación empírica cuyo objetivo fue comprobar el efecto de las figuras retóricas en la construcción de mensajes publicitarios, a partir de dos grupos de doce anuncios con productos deseables e indeseables. Las respuestas indican la idea de que, más que las marcas, son los recursos retóricos utilizados los que tienden a ser determinantes en los índices de recuerdo y de voluntad de compra de los productos anunciados.

Palabras-Ilave: Publicidad, retórica, comunicación, marcas.

I HAVE THE POWER: THE INFLUENCE OF RHETORIC FIGURES OVER PRINT ADVERTISING

Abstract: This paper aims at presenting the results of an empirical research focused on analyzing the effectiveness of rhetoric figures in creating advertisements. The study has been conducted based on twelve advertisements of both desirable and undesirable products. The results show that rhetorical resources, more than brands, tend to be decisive when it comes to remembering the products advertised as well as increasing the desire to buy them.

Key words: Advertising, rhetoric, communication, brands 


\section{INTRODUÇÃO}

Retórica. A arte/ciência surgida no alvorecer da civilização ocidental passou, nesses 2.300 anos por tantas alterações e deturpações de sentido que chega à segunda década do século XXI com sua imagem chamuscada pelo mau uso e pelas camadas de simplificações levianas ou inconsequentes que o homem comum deu a ela.

Surgida no cadinho dos mestres Górgias, Platão e Aristóteles, a retórica precisa ser resignificada logo de início, mesmo em trabalhos científicos, para que olhares incautos não a confundam com o palavrório empolado e inconsistente, do qual muitos se servem, políticos em especial, para desviar a atenção do conteúdo, valorizando somente a forma das mensagens.

A arte/ciência da retórica trata das habilidades ligadas à persuasão. Nela, atenção é data à estruturação formal de uma peça argumentativa bem como dos elementos ligados à transmissão da mensagem com vistas à clara e eficaz provisão de informações para a tomada de decisão ou para a fixação da mensagem na mente do auditório. Sábio, o mestre de Estagira, Aristóteles, observou que não apenas de argumentação racional se faz o processo persuasivo, mas também da capacidade de tocar emocionalmente o público e transmitir mensagem com credibilidade. Assim, os princípios da retórica clássica servem especialmente bem a quem estuda os processos persuasivos da publicidade como é nosso caso. Razão, emoção e credibilidade são os eixos sobre os quais o discurso publicitário se assenta, do mesmo modo que a retórica se sustenta sobre Ethos, Pathos e Logos. Nada de novo sob o sol.

O século $X X$ assistiu à renovação do interesse de pesquisadores, teóricos do direito, da filosofia e da comunicação pelo assunto, dos quais é importante ressaltar o trabalho de Perelmann (2002) dentre diversos outros grandes nomes que já se dedicaram à questão, entre os quais, talvez também valha destacar Barthes (1975), que classifica a retórica como uma proto-ciência, pois seu inventio é fundamental na construção da questão que o cientista fará a si mesmo e cuja resposta poderá trazer uma descoberta, ou levar a novidades inconsistentes, irrelevantes. No campo da comunicação Toulmin (2006) desenvolveu, a partir da lógica, o modelo adotado por muitos estudiosos de retórica da publicidade, que decupa o argumento em bases, garantias e sustentação (groud, warrant e backing) para apoiar a afirmação (claim). 
Talvez o estudo mais representativo, e mais citado, entre os autores que frequentam o ambiente da retórica publicitária seja os dos professores Edward F. McQuarrie e David G. Mick. Seu trabalho de 1996, denominado Figures of Rhetoric in Advertising Language publicado no Journal of Consumer Research classifica as figuras retóricas em ordem de sofisticação dessas figuras, passando dos padrões mais esquemáticos, de fácil codificação, caminhando por figuras de estilo mais e mais trópicas com desvios semânticos que exigem do leitor capacidade de decodificação e associação superiores. A partir dessa escala, os autores fizeram uma seleção de títulos de anúncios que correspondessem às figuras listadas e os testaram junto a estudantes, validando uma taxonomia das figuras retóricas. O trabalho de McQuarrie e Mick tornou-se logo referência devido ao fôlego e consistência dos dados apresentados.

Foi a partir dessa constatação que decidimos utilizar o trabalho dos estudiosos citados para empreender um estudo empírico que validadesse as descobertas dos pesquisadores entre os brasileiros, e que, além disso, nos possibilitasse verificar a efetividade das figuras retóricas como recursos publicitários capazes de aumentar o índice de lembrança dos consumidores acerca da mensagem veiculada e da marca anunciante.

O presente trabalho exibe os resultados da pesquisa aplicada junto a 190 estudantes de publicidade de $1^{\circ}$ semestre da Universidade Presbiteriana Mackenzie em março de 2012, que testa lembrança e desejo de compra, gerados a partir de mensagens textuais e visuais propagados em anúncios impressos.

Para melhor entendermos as bases sobre as quais a atual pesquisa foi estruturada, é necessário conhecermos um pouco mais a fundo o trabalho de McQuarrie e Mick que deu origem à pesquisa que apresentaremos ao longo desse estudo.

\section{UMA TAXONOMIA DAS FIGURAS RETÓRICAS}

Uma figura retórica pode ser definida como um desvio artístico sob a forma tomada por um enunciado. Desde a antiguidade, dezenas destas figuras têm sido catalogadas. Frequentemente percebe-se o uso de figuras retóricas no meio publicitário impresso.

O trabalho de McQuarrie e Mick com figuras de retórica na linguagem pu- 
blicitária diz que há na publicidade não algumas, mas todas as figuras clássicas da retórica que o se definiu como o ponto de partida empírico e seu intuito classificatório. Este trabalho foi constituído, por uma grande amostra de revistas contemporâneas - mais concretamente, por 621 anúncios publicados em 1990 e 1991 nas revistas People, Business Week, Car and Driver, Sports Illustrated, Cosmopolitan e Good Housekeeping.

Um dos pontos de partida do trabalho desses pesquisadores foi o estabelecimento de quatro operações retóricas que poderiam ser definidas como 'a operação que seleciona uma expressão tal que o contexto inicial torna o seu significado indeterminado'. Por indeterminado entende-se que são possíveis múltiplos significados, nenhum dos quais garante uma interpretação definitiva. McQuarrie e Mick detalharam cada figura retórica utilizada na linguagem publicitária, abarcando quatro tipos de operações: a repetição, a reversão, a substituição e a desestabilização; que seguem uma gradação de desvio da linguagem convencional. De acordo com os autores, como objetos estéticos em geral, uma figura retórica proporciona sentido por fazer com que o familiar soe estranho. O desvio, então, é uma maneira de fazer o que em criação publicitária, ou nas teorias que sustentam o humor, chama-se incongruência (Berger, 1998) e dela extrair interesse pela marca ou produto anunciado e prazer pela habilidade como a mensagem central foi desviada, possibilitando variações de sentido e consequente enriquecimento da mensagem.

As figuras de repetição são aquelas que combinam múltiplas instâncias de alguns elementos da expressão sem mudar o sentido de cada elemento. Na reversão, há uma operação que combina elementos que são imagens espelhadas uma da outra na mesma expressão. A substituição seleciona uma expressão que requer um ajuste pelo receptor da mensagem para que se acesse o conteúdo pretendido. Já a desestabilização trabalha, em geral com o uso duplo do conceito, no primeiro indica uma troca, enquanto no segundo estabelece-se a insegurança.

Consideradas essas quatro operações básicas de sentido, os autores propuseram uma escala crescente de distanciamento da apreensão imediata, tradicional ou rotineira de um conceito. Nessa escala, parte-se das figuras onde preponderam os esquemas (schemes) e segue-se em direção às figuras mais complexas, em que prevalecem os tropos. Tropos são encaminhamentos de 
irregularidades conceituais, dependendo de maior ou menor complexidade, carrega substituição (hipérbole, elipse, questão retórica, metonímia) e desestabilização (metáfora, ironia, paradoxo), em variados graus de desvio.

Dentre as conclusões dos autores, sobressai a ideia de que os respondentes tenderam a lembrar-se mais das figuras complexas, estivessem elas presentes nos títulos dos anúncios ou em suas imagens. As experiências com imagens e títulos independentes demonstraram que os mesmos processos de desafio, decodificação e lembrança se manteve, fosse a fonte textual ou visual. Assim, os pesquisadores concluiram que anúncios enriquecidos de figuras retóricas têm melhores possibilidades de cativar a atenção dos consumidores e de serem lembrados por eles.

A partir desse instigante estudo, propusemo-nos produzir um trabalho que se concentrasse menos na taxonomia das figuras retóricas presentes nas peças publicitárias e mais na verificação da efetividade das figuras, enquanto elementos catalizadores de lembrança das peças, objetivo similar ao dos pesquisadores estrangeiros - e a verificação da possível existência de relação entre a presença de figuras e ampliação do desejo de compra. Esse objetivo ensejou a criação de dois grupos de anúncios a serem analisados como passaremos a descrever em seguida.

\section{O ESTUDO EMPÍRICO}

O estudo empreendido teve por objetivo verificar se o uso de recursos retóricos surtiria efeito no aumento da performance das peças publicitárias. Para determinar o que seria considerado elemento de qualificação do desempenho dos anúncios, definiu-se a lembrança das mensagens como fator preponderante na performance das peças.

A lembrança da mensagem, contudo, precisou ser subdividade em três eixos para que se pudesse avaliar a efetividade das figuras de linguagem. A lembrança da mensagem/copy (SAMPAIO, 1995, p.332), a lembrança da mensagem visual/imagética e o desejo de compra despertado pela peça. O termo copy é aqui utilizado na acepção dada pelas agências de publicidade norte-americanas, expressando, essencialmente, a ideia conceitual expressa na mensagem textual presente na peça. Em geral, quando se designa copy, remete-se ao texto (título, texto e assinatura) presentes nas peças publicitárias, então, ambiguamente, copy designa a mensagem. 
O estabelecimento do instrumento de pesquisa necessitou de um amplo levantamento dos anúncios impressos veiculados nas revistas Veja, Caras, Robb Report, Black Card, Vogue, Alfa, Época, Daslu, Atrevida, Capricho, GQ, Hola Brasil, Isto é, Isto é Dinheiro, Joyce Pascowich, Newsweek, Oprah, PME, Quem, Propaganda, The Economist, TPM e Vip dos quais selecionou-se, por julgamento, 24 anúncios que correspondiam aos seguintes critérios: sofisticação crescente do nível de desvio presente nas peças; variação de predominância de discurso visual/textual; presença dos elementos básicos - título, imagem e assinatura; variação do uso de recursos para capturar a atenção (sexo, humor, non-sense, etc...).

Além disso, como se objetivou verificar o desejo de compra do produto/ serviço anunciado. Optou-se pelo teste de dois grupos de anúncios sobre os quais se efetivavam as mesmas questões. O primeiro grupo, de 12 anúncios trazia ofertas de produtos considerados “desejáveis" para o público alvo definido. O segundo grupo (de controle) trazia nova série de 12 anúncios, porém de produtos voltados para diferentes públicos-alvo. Ambas as séries de anúncios foram ordenadas de forma que houvesse crescente dificuldade de decodificação das mensagens, uma vez que os recursos retóricos utilizados afastavam-se dos esquemas e caminhavam para proposições mais trópicas.

Sobre os dois grupos de anúncios, solicitou-se dos respondentes que, após a visão integral da série (20 segundos de exibição de cada anúncio) listassem as chamadas, imagens, e marcas mais lembradas. Pediu-se também que apontassem se o anúncio estimulou o desejo de compra do produto anunciado. Os questionários traziam apenas questões abertas e só eram distribuídos aos respondentes após a exibição no data-show de cada série de anúncios. Os questionários traziam as seguintes perguntas: De quais imagens você se lembra? De quais mensagens você se lembra? Com quais anúncios você se identificou? De que marcas você se lembra? Quais anúncios causaram efeito positivo e negativo? Algum dos produtos/serviços anunciados provocou o desejo de compra? Quais? Algum dos anúncios diminuiu seu interesse pela marca? Qual?

Os respondentes foram 190 jovens estudantes de $1^{\circ}$ semestre do curso de publicidade da Universidade Presbiteriana Mackenzie. O procedimento ocorreu em dias alternados em março de 2012. A escolha desse jovem grupo se deu devido a percepção de que os calouros conhecem pouco as teorias de comunicação 
e tem menor desenvoltura e repertório que discentes dos semestres superiores. Além disso, por estarem todos na mesma faixa etária e situação socio-econômica similar, pudemos obter certa homogeneidade no grupo de respondentes.

Os resultados obtidos apontam para conclusões interessantes. O primeiro grupo de respostas, acerca de anúncios de produtos desejáveis trouxe os seguintes resultados:

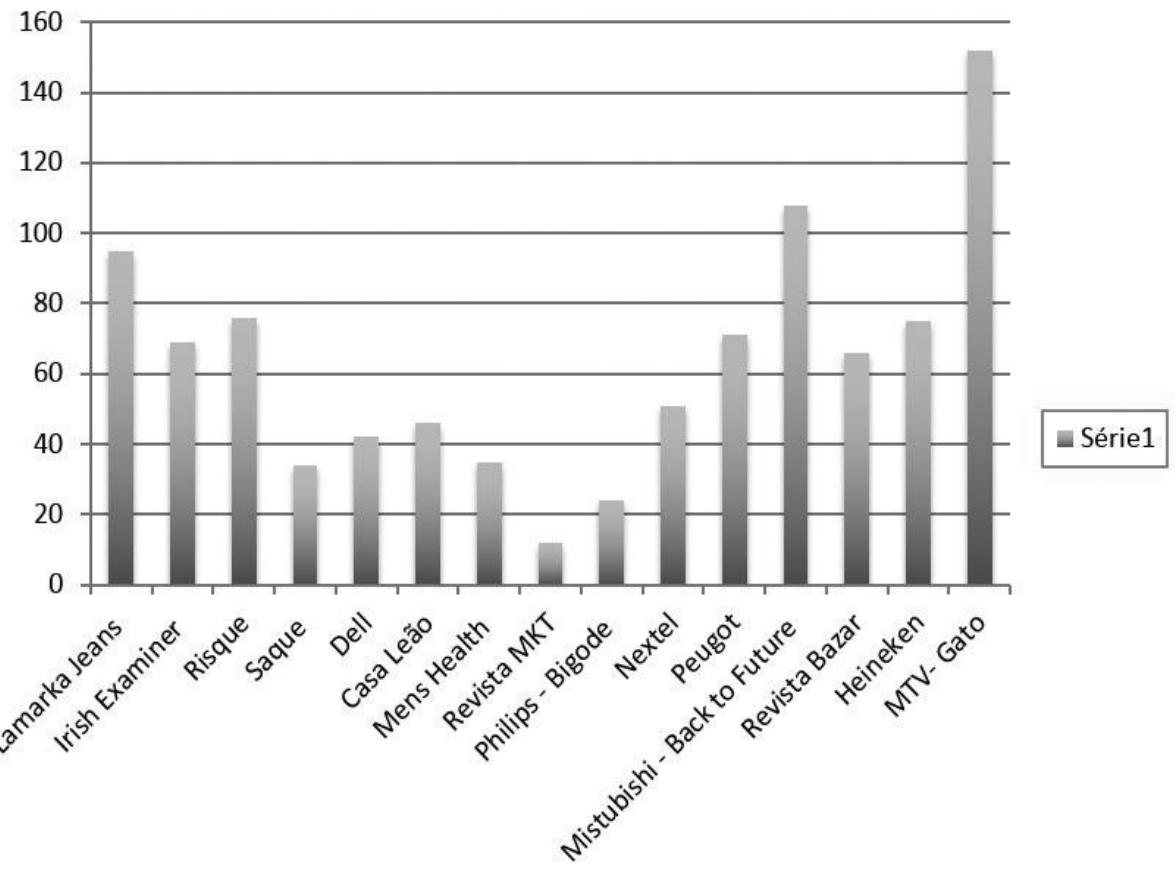

Gráfico 1 - Produtos desejados - imagens lembradas

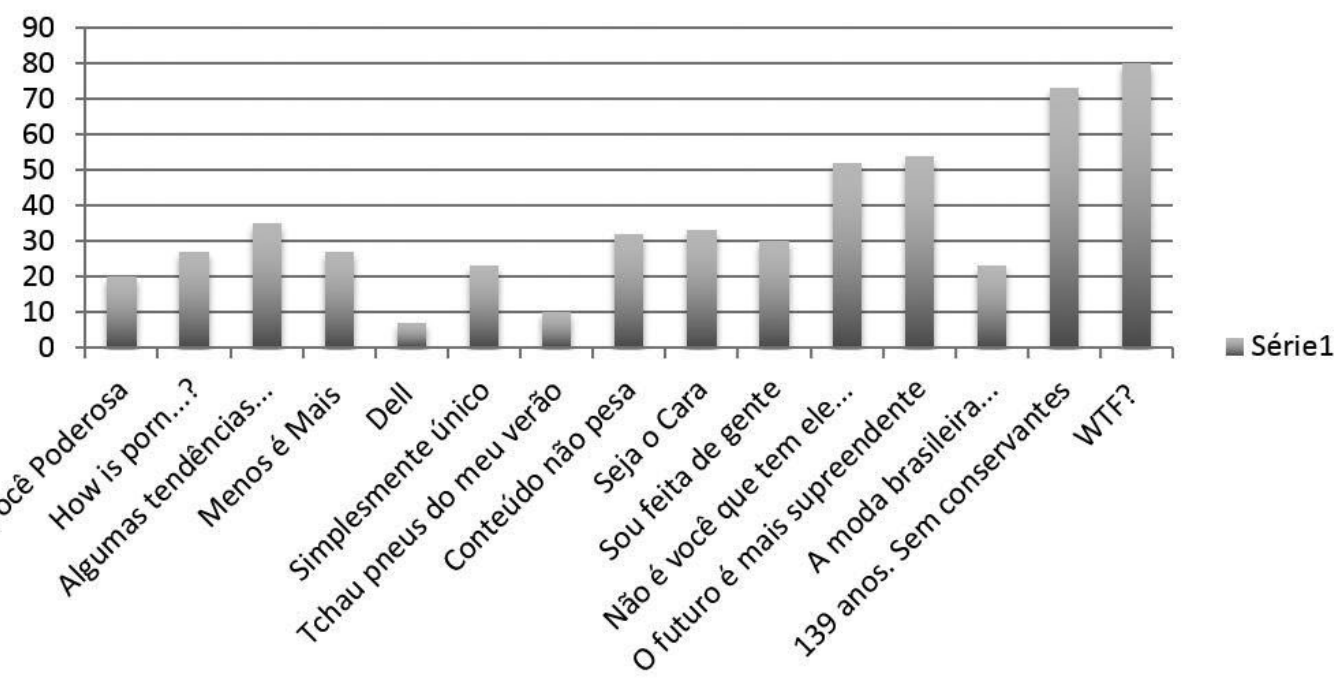

Gráfico 2 - Produtos desejados - mensagens lembradas 
A primeira série comparativa demonstra a preponderância das mensagens visuais, sendo que a imagem mais lembrada obteve 152 respostas positivas, ou 80\% de índice de lembrança.
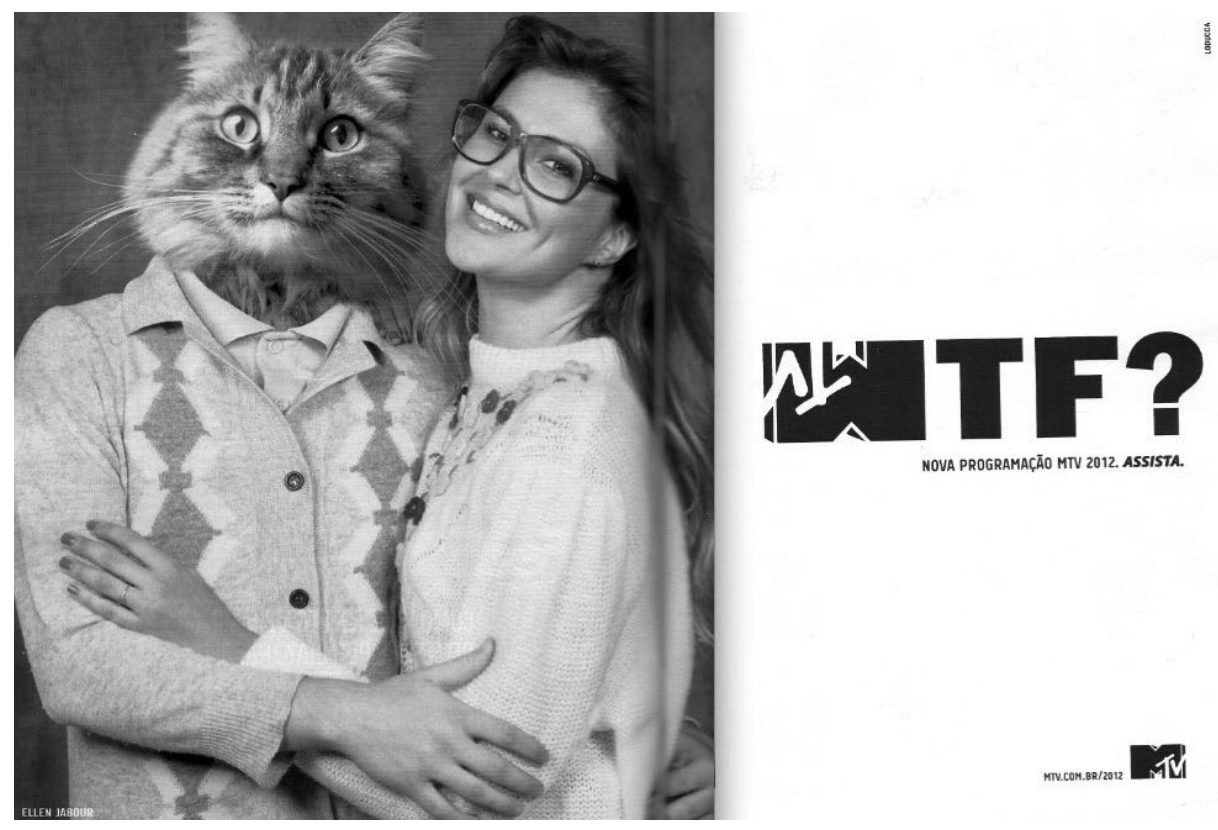

Figura 1 - Anúncio mais lembrado - MTV

A situação de non-sense da peça publicitária, associada a uma marca que detém boa imagem junto ao público jovem, a MTV, talvez tenham sido os fatores determinantes para o alto índice de lembrança obtido. Ressalte-se que se trata de um anúncio de difícil decodificação, pois exige amplo repertório - inclusive da língua inglesa, ou ao menos da expresão WTF (what the fuck) típica dos jovens norte-americanos, e sua transposição para a logomarca da emissora apresentanda de cabeça para baixo. A distância formal entre a imagem e a mensagem textual "WTF? Nova programação MTV 2012. Assista." Exige do leitor habilidade para fazer operações a associações sígnicas entre título, imagem e assinatura. Esse mesmo anúncio também foi o mais lembrado quando o questionamento recaiu sobre a estratégia textual da mensagem. A expressão WTF? Obteve 80 respostas, ou $42 \%$ de lembrança.

Em oposição, o anúncio com menor índice de lembrança imagética foi o dos barbeadores Philips. Descartamos o anúncio da Revista Marketing por ser 
um all type ${ }^{1}$ o que desvia o resultado acerca de imagem mais lembrada; essa peça publicitária apresenta diagramação ousada, mas com baixo índice de retenção, 12,6\%. Seu título, contudo, um caso clássico de repetição, ou esquema, obteve apenas $17 \%$ de lembrança.

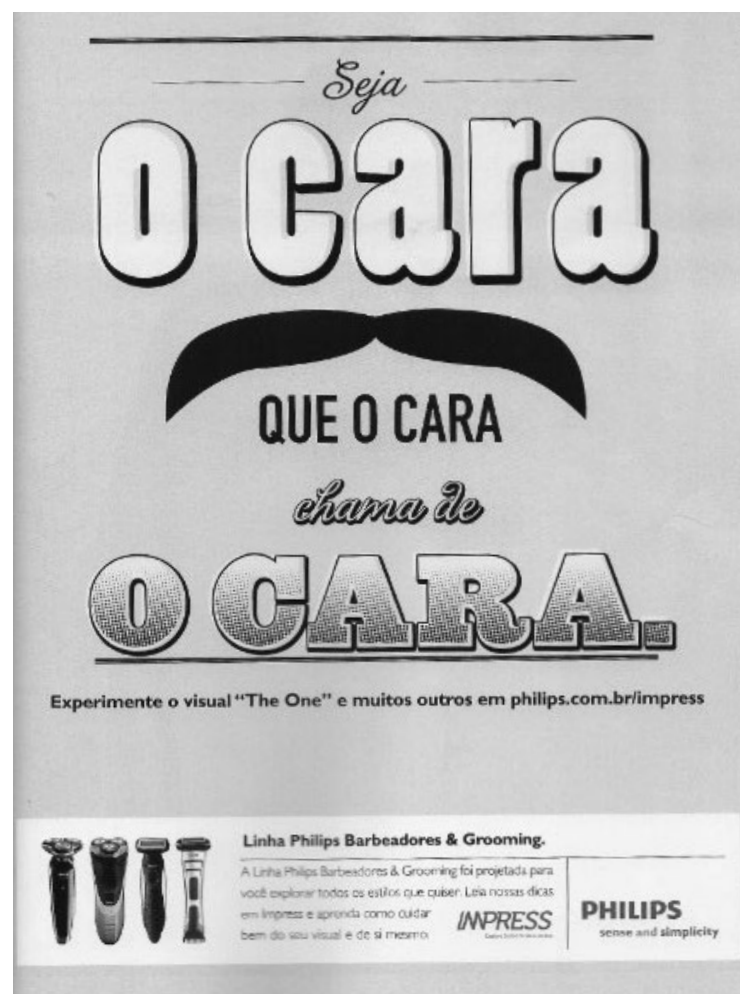

Figura 2 - Anúncio Philips

O que se pode notar é que a ousadia visual da peça acima não foi suficiente para reter a atenção e lembrança dos respondentes. O sistema retórico de esquema, com a repeticação da expressão 'o cara', com diferentes sentidos foi, nesse caso, ineficaz para garantir a lembrança da mensagem.

Entre os produtos considerados indesejados, notou-se comportamento similar conforme mostram os gráficos a seguir.

10 termo all type designa peças publicitárias compostas apenas por texto, sem o apoio da imagem. No caso em tela, o anúncio referido foi descartado porque nesse momento avalia-se a "imagem mais lembrada", então um anúncio com essas características não pode concorrer diretamente com outros que utilizam imagens no composto da mensagem. 




Gráfico 3 - Produtos indesejaveis - imagens lembradas

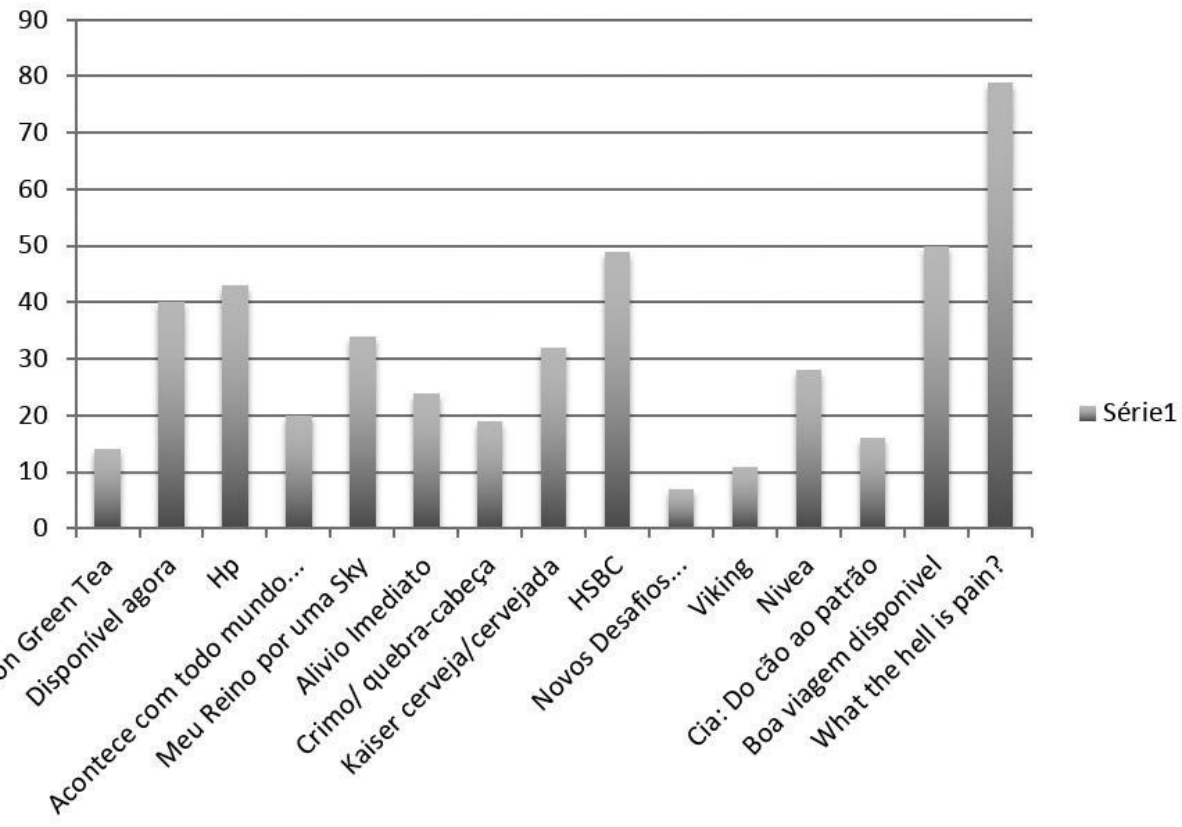

Gráfico 4 - Produtos indesejáveis - mensagens lembradas

Dentre os representantes do segundo grupo de anúncios exibidos aos respondentes, verificou-se que o anúncio de chá Lipton obteve maior índice de lembrança, 59,4\%, seguido pela imagem mais lembrada, pertencente a um anúncio de emplastros medicinais. A exuberância da imagem desse segundo anúncio pode ajudar a explicar os altos índices de lembrança $41,5 \%$ obtidos apesar da marca Deep Cold Patch ser desconhecida do público. 


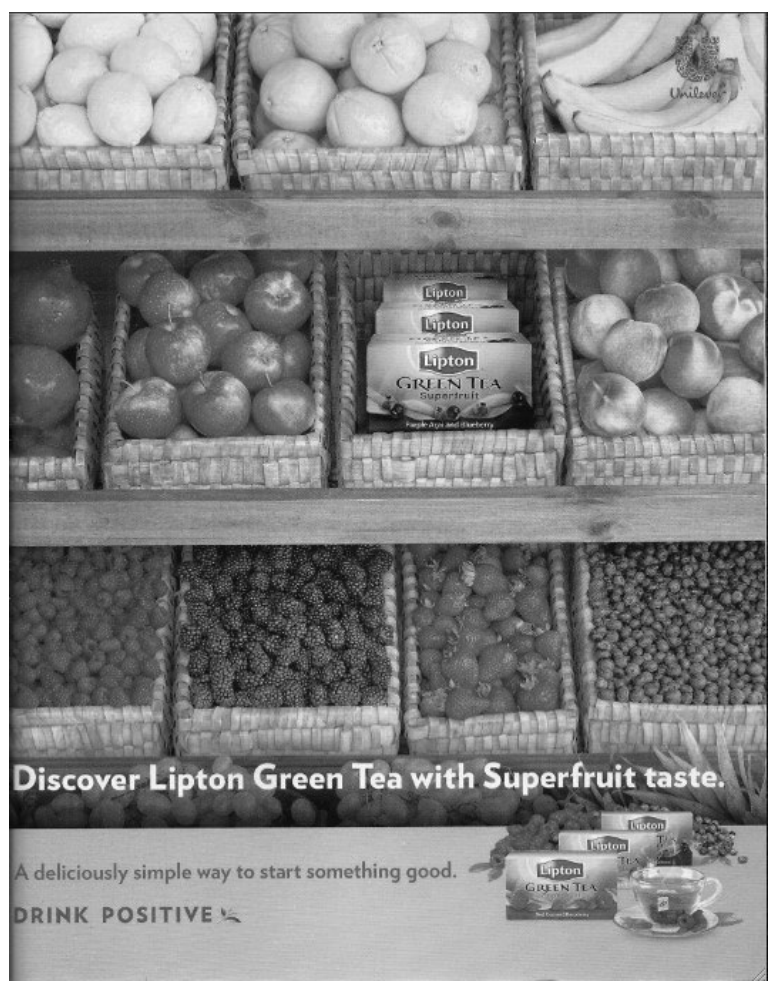

Figura 3 - Anúncio Lipton

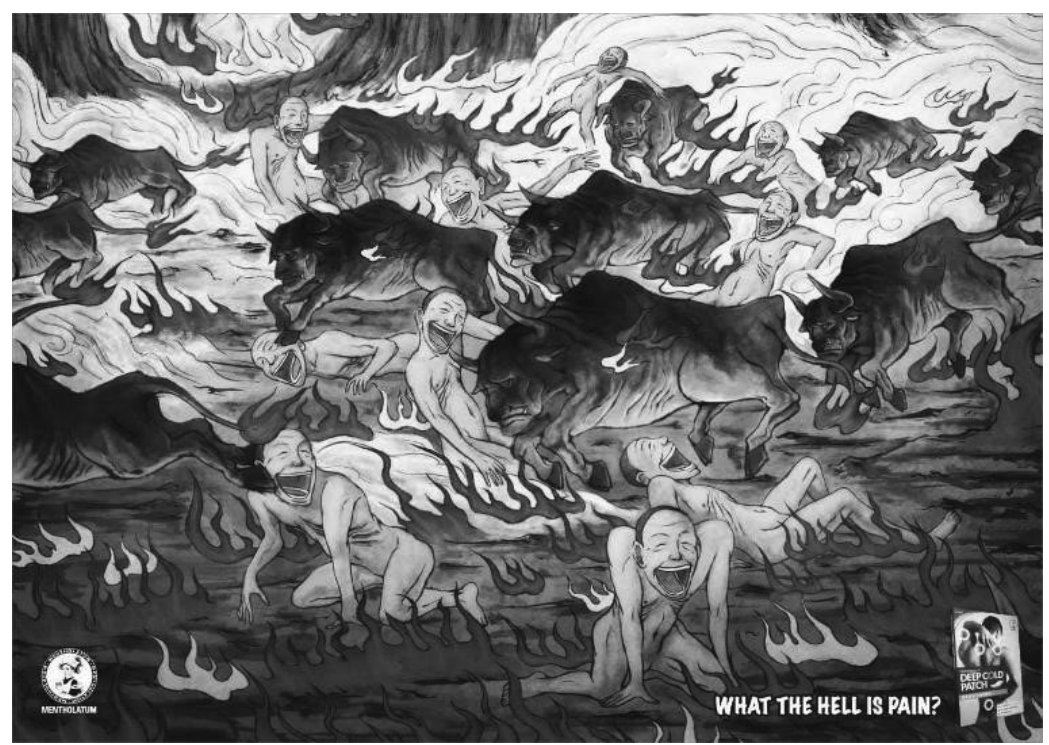

Figura 4 - Anúncio emplastro Deep Cold Patch

Curioso, portanto o resultado visual do anúncio da Lipton, cujo nível de desvio retórico ou de ousadia gráfica deixa muito a desejar se comparado ao anúncio acima. Uma das hipóteses para esse resultado é o fato de esse anúncio ter sido o primeiro da série exibida. Outra possibilidade é que, nesse caso, o 
sistema esquemático de simples substituição da fruta pelo chá tenha agradado ao grupo de respondentes.

Outrossim, a titulação do anúcio de emplastro obteve resultados superiores ao anúncio de chá, pois carrega consigo uma questão de alto impacto: "what th hell is pain?" (O que é a dor?), com o trocadilho verbo/visual presente no uso ambíguo da palavra hell - inferno.

Já, entre as marcas mais lembradas, foram obtidas 154 respostas positivas. Verifou-se $81 \%$ de recall no anúncio de marca de cerveja que não detém liderança no mercado, a Heineken, enquanto que a peça voltada para o mercado profissional (trade) da mal-afamada cerveja Kaiser empatou com a peça publicitária da Microsoft voltada para a venda de espaços na nuvem com 133 respostas ou $70 \%$ de lembrança.

\section{ANOS SEM CONSERVANTES.}

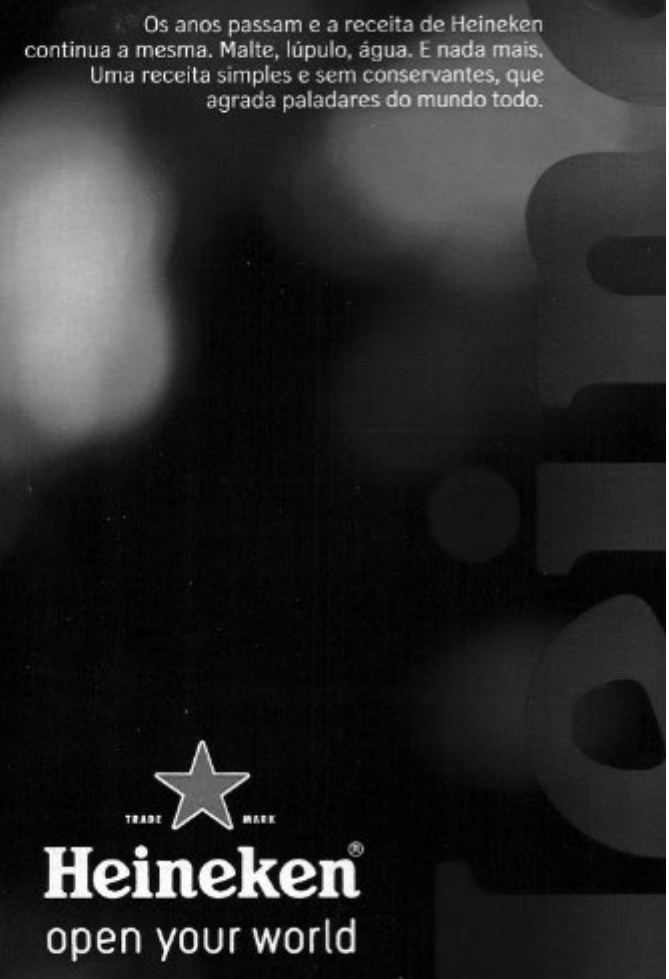

Figura 5 - Anúncio Heineken 


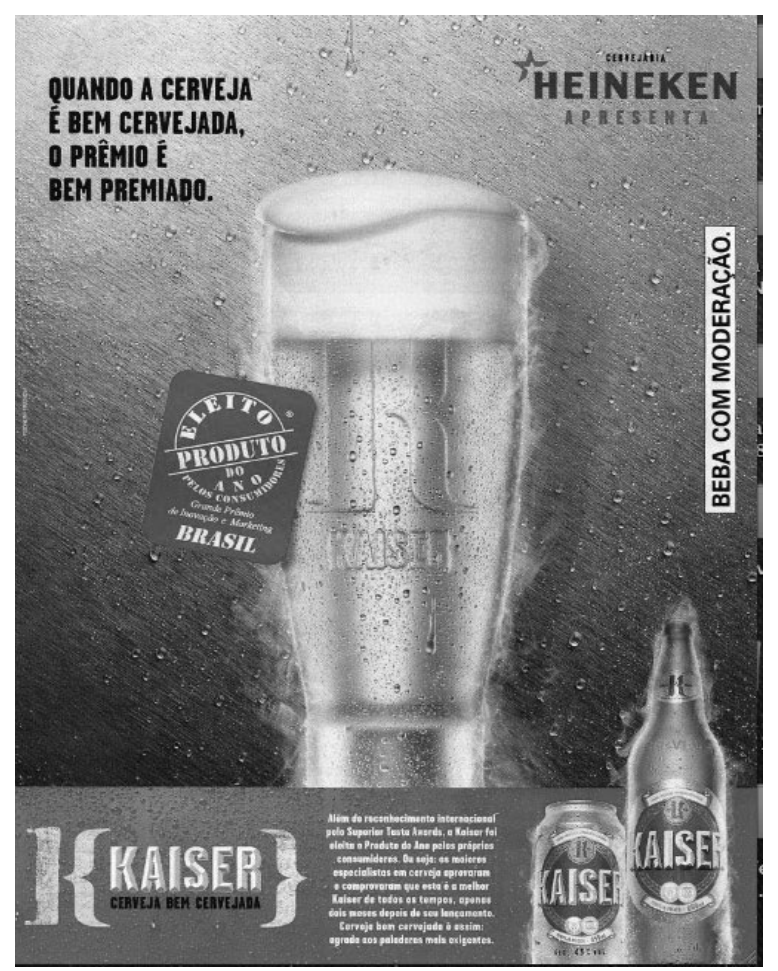

Figura 6 - Anúncio Kaiser

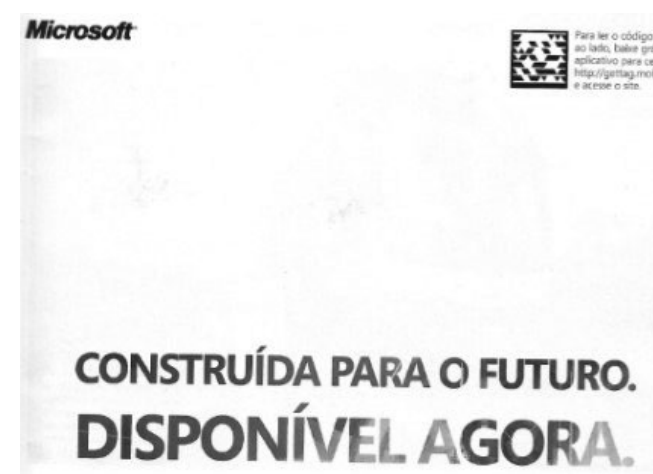

Solução de Nuvem Privada da Microsoft. Saiba mais em microsoftcom.br/nuvemprivada

OWindows Server | SystemCenter

Figura 7 - Anúncio Microsoft



Gráfico 5 - Lembrança de marcas desejadas 


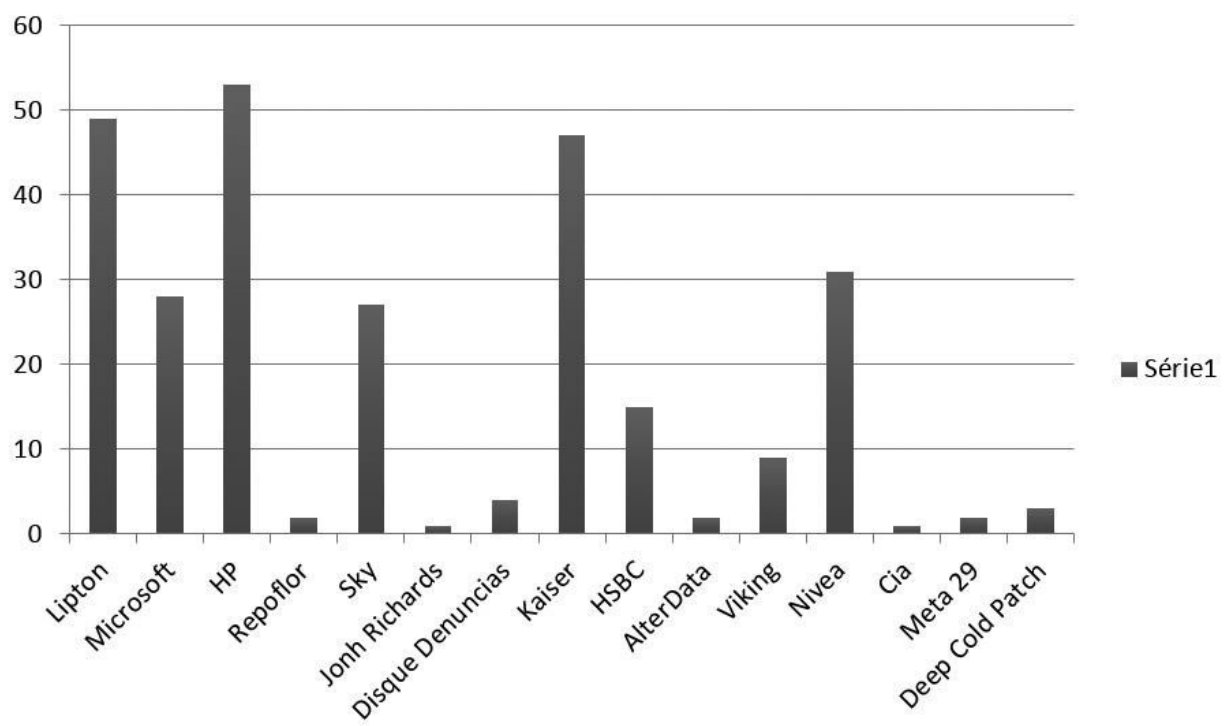

Gráfico 6 - Lembrança de marcas indesejadas

Uma leitura atenta dos resultados - e de outros obtidos nesse mesmo estudo, que pela limitação espacial não poderemos apronfundar aqui - leva a crer que não obstante a imagem existente sobre as marcas anunciantes pode-se verificar que as peças publicitárias obtiveram ótimos índices de lembrança. Assim emerge curiosa conclusão: talvez não exista relação entre a lembrança de uma peça publicitária e a imagem que a marca anunciante detém junto ao público alvo. Essa conclusão enseja discussão mais aprofundada que trataremos adiante.

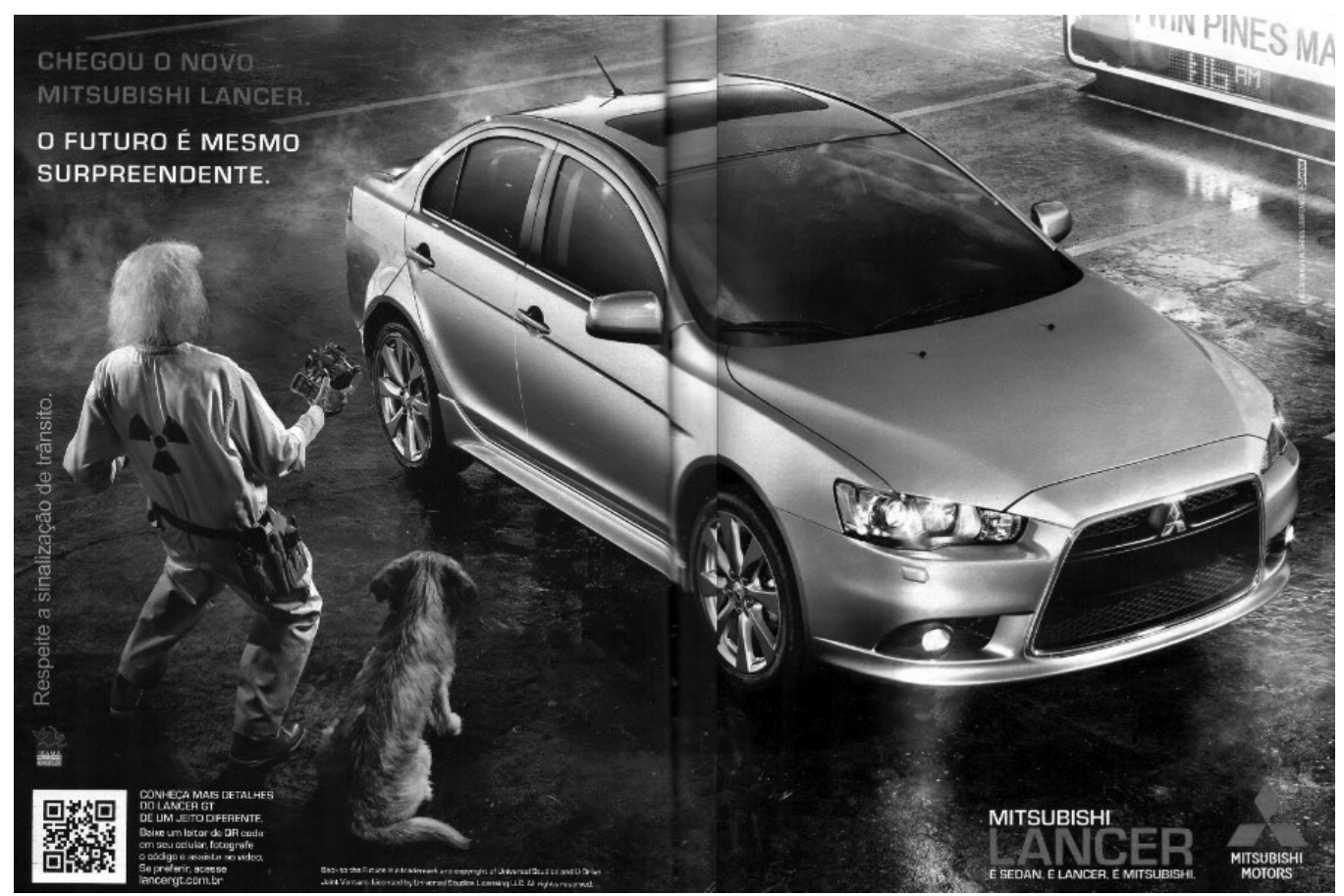

Figura 8 - Anúncio Mitsubishi 
Para concluir a apresentação dos principais resultados que o presente estudo indicia é preciso demostrar como os respondentes reagiram à questão acerca de desejo de compra. É claro que dito diretamente, esse questionamento pode levar a distorções dos resultados, contudo, ainda assim, os resultados surpreendem.

Entre os produtos desejáveis o que mais aumentou o desejo de compra dos respondentes foi o veículo da Mitsubishi, (43,1\%), enquanto que dentre os produtos indesejáveis o chá verde da Lipton quase empata com a cerveja Kaiser ( $25,7 \%$ e $24,7 \%$ respectivamente) - uma resposta curiosa, entre um grupo de jovens universitários...

O desejo por veículos automotivos é um resultado esperado. Qual o jovem, recém completados os 18 anos que não carrega o desejo por carros. Some-se a isso, o anúncio exibido fazer referência a um filme icônico dos anos 90 e 2000, o De Volta para o Futuro. Já as peças de chá e da cerveja Kaiser obtiveram resultados surpreendentes. O chá Lipton, como já dito, pode ter sido beneficiado por ser a primeira peça a ser exibida na série, também por seu layout ser vistoso, colorido. Também o anúncio da Kaiser, que não era dirigido para o público respondente da pesquisa, talvez tenha conquistado adeptos devido a imagem de "gelada" que a fotografia expressava. Fumacinha e copo suado podem ter sido determinantes na lembrança da peça.

Cabe lembrar que, enquanto a construção retórica da Heineken era bastante sofisticada, tendo, inclusive, eliminado a imagem do produto de seu anúncio, a Kaiser se utilizou de uma fórmula cliché, que é o uso do imagem do copo suado de cerveja gelada. Poderíamos supor que o alto índice de lembrança da Heineken está assentado tanto no anúncio quanto na imagem positiva da marca, enquanto o sucesso da peça da Kaiser assenta-se apenas no "apetite appeal", o apelo ao apetite que a imagem do copo de cerveja provoca.

\section{PUBLICIDADE E BRANDING, MUNDOS PARALELOS}

O discurso da "Comunicação Integrada", dominante no pensamento atual sobre as estratégias de comunicação na publicidade, costuma reforçar a importância da presença de um mesmo conceito criativo ao longo de toda a campanha de comunicação. Isso significa que o ideal é que todas as peças de uma campanha publicitária, bem como as demais ferramentas de marketing 
postas em uso ao longo da campanha utilizem-se do mesmo conceito criativo (Figueiredo, 2005). A ideia central do pensamento de comunicação integrada é que cada ação de comunicação e marketing contribua para a construção e consolidação da mensagem que se deseja fixar na cabeça do consumidor acerca de uma marca, produto ou serviço. Esse pensamento coincide com a proposição dos pensadores de design quando tratam do tema branding (Klein, 2002) que defende a construção de uma imagem e personalidade para as marcas que as distingam de seus concorrentes em termos subjetivos, abstratos. Segundo essa corrente, a construção da imagem de marca está intensamente associada à capacidade dos fornecedores de comunicação de uma marca em criar e manter os conceitos centrais das marcas não obstando a ferramenta de marketing a ser utilizada em cada ação da companhia.

A experiência das empresas sustenta a hipótese de que as ações de comunicação integrada e de branding levam à melhor gestão dos recusos de marketing uma vez que a homogeneização da mensagem diminui o ruído das peças de comunicação e aumenta o índice de lembraça das marcas e suas mensagens por parte dos consumidores. Funciona simbióticamente: cada ação de comunicação apoiando e ajundando o consumidor a lembrar-se da outra uma vez que ambas, ou todas, detém o mesmo conceito criativo, e portanto, a mesma mensagem acerca da marca anunciada.

Os resultados do presente estudo, contudo, trazem uma nova incógnita a ser analisada. Trata-se do fato de termos verificado que o efeito da mensagem publicitária nem sempre coincide com a imagem que as marcas detém junto aos seus públicos alvo. Em outros termos, a pesquisa ora apresentada demonstra que os índices de lembrança não estão diretamente correlacionados com marcas anunciantes, estando mais diretamente associados aos recursos retóricos utilizados em sua criação. Então, de um ponto de vista estritamente baseado em lembrança, pode-se arriscar dizer que a marca foi um fator menos importante que a mensagem veiculada sobre ela. Pelo menos esses são os resultados que o presente estudo indicou. Naturalmente, dada a amplitude da presente afirmação, seria desejável que se executasse nova pesquisa com o fito exclusivo de verificar o exposto. Mesmo assim, nossa discussão leva a crer que as marcas não ocuparam o primeiro plano nos resultados da presente pesquisa. É claro que o sistema utilizado para colher as informações pode levar a essa conclusão, 
pois toda a concentração dos respondentes estava nas mensagens comerciais e não na outra dimensão, mais ampla, do discurso das marcas. As mensagens visuais e textuais - parecem ter dominado o panorama da memória e do desejo dos jovens estudantes que responderam a essa pesquisa. É fato também, que o objeto da pesquisa foi a verificação da potência que os recursos retóricos podem emprestar às marcas anunciantes, fato que se verificou na análise comparativa dos índices de lembranças as mensagens imagéticas e textuais.

Outra conclusão curiosa, é que a contribuição da marca para a lembrança da peça não pôde ser verificada, já que as peças mais lembradas não são aquelas de marcas conhecidas. O efeito momentâneo de prazer, promessa ou desejo presente nas peças publicitárias escolhidas pelo público parece ser mais imediato que os longos e consistentes esforços para a construção das marcas. Não que esses fatores sejam opostos ou que um seja impeditivo do outro, mas parece haver uma divergência entre o discurso e a prática. Enquanto o discurso aponta a crucial importância da construção da marca, nosso estudo parece mostrar que o que importou aos respondentes foi a mensagem veiculada. Para tanto, os recursos retóricos utilizados foram de fundamental importância.

Uma leitura possível é que uma observação dos fenômenos de comunicação publicitária - em especial em curto prazo - leva à percepção de que vale mais o impacto da mensagem imediata que o valor da construção sólida de imagens de marca; talvez aí esteja a explicação para a presença tão ampla e constante de grandes anunciantes que rejeitam raciocínios mais sofisticados de comunicação dirigindo suas verbas para propaganda massiva e massante, ainda que eficaz na capacidade de cativar a lembrança dos consumidores.

O que se observou nesse estudo é que o uso de figuras retóricas incita ao diálogo com a peça publicitária. De modo geral, excetuando-se os afetos às marcas específicas, poderíamos dizer que quanto mais trópica a peça, meIhor seu índice de lembrança. O tropo funciona como uma provocação ao leitor para que ele decifre a peça e, nessa condição, seja partícipe do diálogo com a marca. Como resultado, obtém-se maior chance de lembrança dessas marcas, com as quais o leitor relaciona-se.

É importante ressaltar que haverá, certamente, um limite para o quanto enigmática uma peça possa ser, uma vez que se não for "decifrada" pelo consumidor ele poderá rejeitá-la. O jogo do uso de recursos retóricos, portanto, 
vai além da escolha do canal de contato, priorizando-se no anúncio a credibilidade (ethos) a emoção (pathos) ou a razão, (logos); mas também pelo nível de envolvimento que se espera estabelecer com o consumidor. Assim peças enriquecidas com recursos esquemáticos tenderão a obter menos lembrança que aquelas que se apoiam em mensagens trópicas. Contudo, considerando-se a miríade de variáveis que uma campanha publicitária pode ter, a escolha dos ingredientes a serem misturados nessa panela comunicativa vai muito da sabedoria do chef, e pouco de uma receita prévia. Por outro lado, no panorama atual da comunicação o domínio dos recursos retóricos parece ser fundamental para que criativos consigam produzir propaganda com potencial de catalisar afetos dos consumidores, melhorando sua lembrança e desejo de compra.

\section{REFERÊNCIAS}

BARTHES, Roland. Mitologias. São Paulo, Difel, 1975.

BERGER, Arthur A. An Anatomy of Humor.1a ed. Transaction Publishers, New Jersey, 1998

FIGUEIREDO, Celso. Redação Publicitária: Sedução pela Palavra. $1^{\mathrm{a}}$ ed. Thomson, São Paulo, 2005

KLEIN, Naomi. Sem Logo. Ed. Record, 2002.

MCQUARRIE, Edward F. e MICK, David G. Figures of Rhetoric in Advertising Language. Journal of Consumer Research vol. 22 pág. 424 a 438, março de 1996.

PERELMANN, Chaïn. Tratado da Argumentação - A Nova Retórica. $1^{\mathrm{a}}$ Ed, $5^{\mathrm{a}}$ tiragem, Martins Fontes, São Paulo, 2002

SAMPAIO, Rafael. Propaganda de A a Z. Rio de Janeiro, Campus, 1995.

TOULMIN, Stephen. Os Usos do Argumento. $2^{\mathrm{a}}$ Ed. Martins Fontes. São Paulo, 2006

RECEBIDO EM: 16/05/2013

ACEITO PARA PUBLICAÇÃO: 01/07/2013 


\section{Celso Figueiredo Neto}

É doutor em Comunicação e Semiótica pela PUC-SP, professor pesquisador da Universidade Presbiteriana Mackenzie, responsável acadêmico pelo curso de pós-graduação lato sensu em Marketing e Comunicação Integrada do Mackenzie. É líder do grupo de pesquisa Pario e membro do grupo de pesquisa Narrativas midiáticas, poética e retórica do consumo. É editor do periódico INOVCOM.

\section{Maria de Lourdes Bacha}

É pós doutora em Comunicação e Semiótica pela PUC-SP, docente do Centro de Comunicação e Letras da Universidade Presbiteriana Mackenzie, pesquisadora FAPESP, líder do grupo de pesquisa Comunicação, Culturas e Mídias Contemporâneas-UPM.

\section{Sofia Derani}

É discente em Publicidade na Fundação Armando Alvares Penteado. 